\title{
POSSIBILITIES OF PLUM CULTIVATION IN THE REPUBLIC OF SERBIA
}

\author{
Milutin Matković ${ }^{1}$
}

\section{Summary}

Cultivation od plums has always been one of the most important parts of Serbian agriculture. In modern Serbian history cultivation of plums is among main parts of it's economy, being one of the first export products of modern Serbia.

Agriculture is marked as one of the motors of revitalization of Serbian economy. Plum is the most common Serbian fruit species. Serbia is in top five countries with area under plum. Western Europe has biggest market for plum and products of plum in the world. Serbian plum export is insignificant. Serbia has the potential to become a regional leader in plum export. Variable results in plum cultivation states the plum cultivation needs modernization in every aspect in order to achieve modern level of cultivation of plums.

In order to revive plum cultivation and make it profitable for export, comperhensive action which includes all relevant factors is nededed. This article will try to give insight in state of cultivation of plums and suggest posible guidelines in it's revitalization.

Key words: cultivation, plums, development, export, revitalization

JEL: $Q 130$

\section{Introduction}

Serbia has great potential in agriculture. During modern time history it has mainly been recognized as agricultural country. One of the most important products of Serbian agriculture is plum.

Plum growing in among oldest agricultural disciplines in Serbia. Of all fruit trees in Serbia more than $50 \%$ are plum trees. In the modern historie there were times when plum was only Serbian export product. For decades dryed plum was one of the best seling export products of Serbian economy. Today Serbian plum export is so low that it is irelevant in economic terms.

1 Milutin Matković, MSc, Ph.D. student, Krusevačka street no. 21, 11000 Belgrade, Republic of Serbia, Phone: +381 642787 238, E-mail: milutin.matkovic@gmail.com 
Thare are many problems in plum cultivation in Serbia today. Sorting, mehanization, metods of cultivation, alteration, storage, are amongst other, problems that needs to be deald with if plum is going to become considerable export product of Serbia.

Since it is national goal to establish Serbia as profitable and recognisable agricutural country, cultivation of plums should be one of the main ways of acheveing those goals, not only because of it's importance in the past, but also for great potential that lies within. All of this won't be possible without proper state guided vision and strategy, that will make path for revitalization of plum cultivation in Serbia.

\section{Methodology and data sources}

Analysis of variance and models of linear trend were used for cultivation analysis, while for comparing of Serbia and other countries comparative method was used.

For need of this article data from several sources were used, books concerning plum cultivation, statistical sites of world organizations, bulletins from conferences about plum held in Serbia, as well as scientific journals, in order to gain more comprehensive picture of place that plum cultivation of Serbia has today.

Goal of this article is to show strengths and weakness of Serbian plum cultivation, and to point to the possible ways of improving plum cultivation. This article will try compare state of Serbian plum cultivation with state of cultivation of plum in region and other significant plum cultivating countries.

\section{Production}

Of all areas harvested with fruit, $67 \%$ goes on stone fruit, two third of which are areas under plum. In overall annual production of fruit in Serbia stone fruit participates with $57 \%$. Orchards in Serbia occupy $4.8 \%$ of area under agricultural land. More than $50 \%$ of that is plum orchards. Number of fruit crops for consumption in fresh state is low (Keserović et al., 2012).

Cultivation of plums faces many problems in Serbia today, seedlings, plum variety, cultivation methods, mechanization, production stagnation, decline in yields, age of trees, inadequate orchards...

Main problem in cultivation of plum in Serbia is extensive production, which characterize low level of agricultural techniques and low yield (Keserović et al., 2012). More than $50 \%$ of plum crops are grown extensively.

Serbia holds second place (table 1), after China, with 158.000 ha under plum trees, which is $6.24 \%$ of total world area under plum. It can be seen from Table 1. that Serbia has double of more area under plum than countries in region, and holds first place in Europe, whit Bosnia and Romania, far behind with 79.000 and 67.478 ha. All the other countries in the region have less than 20.000 ha under plum. 
Table 1. Participation of countries in the structure of surface under plum

\begin{tabular}{|c|c|c|}
\hline Country & area in ha & area in percentage \\
\hline China & $1,752,675$ & 69.2 \\
\hline Serbia & 158,000 & 6.24 \\
\hline Bosnia and Herzegovina & 79,000 & 3.12 \\
\hline Romania & 67,478 & 2.66 \\
\hline Turkey & 20,468 & 0.80 \\
\hline Bulgaria & 17,776 & 0.70 \\
\hline Italy & 11,636 & 0.45 \\
\hline Hungary & 5,700 & 0.22 \\
\hline Germany & 3,863 & 0.15 \\
\hline world in total & $2,531,479$ & 100 \\
\hline
\end{tabular}

Source: fao.org, 2014.

With average annual production of 400.000 ton(t), Serbia is in third place among plum producers in the world, behind China and Romania.

Table 2. World plum producers

\begin{tabular}{|c|c|c|}
\hline Country & annual production (t) & production in percentage \\
\hline China & $6,022,744$ & 56.2 \\
\hline Romania & 424,068 & 3.96 \\
\hline Serbia & 391,485 & 3.65 \\
\hline Turkey & 297,026 & 2.77 \\
\hline Italy & 172,247 & 1.60 \\
\hline Bosnia & 111,005 & 1.03 \\
\hline Hungary & 43,268 & 0.04 \\
\hline world in total & $10,702,774$ & 100 \\
\hline
\end{tabular}

Source: fao.org, 2014. 
It can be seen in Table 2, that countries with significantly less area under plum, have similar annual production, which indicates that Serbia isn't using her full potential in

plum growing. Reasons for this state are several, main of which are extensive production and yield decrement in last several decades. For example Chile has 21.000 ha under plum and annual production for 2012 of 300.000 ton. In the region Romania has larger annual production average than Serbia, other significant producers are Italy and Bosnia, while other regional countries have minor production of plums.

Greatest problem of plum cultivation in Serbia is yield, which is in constant decline and beneath world average for 0.95 ton per hectare (t/ha). This puts Serbia in 62'nd place in the world and 27't place in Europe (Table 3.). Main reason for low results in yield is extensive production, that doesn't give possibility for modern cultivation.

Table 3. Yield of plums in $t / h a$ for some countries

\begin{tabular}{|c|c|}
\hline Country & yield in t/ha \\
\hline Slovakia & 25.45 \\
\hline Lebanon & 16.80 \\
\hline Italy & 12.90 \\
\hline Greece & 11.20 \\
\hline Serbia & 3.2 \\
\hline world in average & 4.15 \\
\hline
\end{tabular}

Source: Čobrda, 2005.

This is an obvious indicator that Serbian fruit cultivation methods are surpassed. If untraditional plum cultivating countries such as Lebanon can achieve several times bigger yield, than it is understood that changes are needed if Serbia wants to revitalize plum cultivation.

Serbia has 39.530 million bearing trees, and this number is the parameter that is keeping Serbia among top producers in the world. But, on the other hand, number of trees is also decreasing. Serbia lost $25 \%$ of bearing plum trees in last three decades (Tables 4 and 5). Number of bearing trees decreased at annual rate by $0.59 \%$. 
Table 4. Number of bearing trees in Serbia (1980-2006)

\begin{tabular}{|c|c|}
\hline Year & number of trees in 000 \\
\hline 1981 & 49,839 \\
\hline 1985 & 48,068 \\
\hline 1990 & 46,395 \\
\hline 1995 & 44,652 \\
\hline 2000 & 43,104 \\
\hline 2005 & 42,582 \\
\hline 2006 & 41,796 \\
\hline
\end{tabular}

Source: Matković, 2008.

Table 5. Number of bearing trees in Serbia (2007-2013)

\begin{tabular}{|c|c|}
\hline Year & number of trees in 000 \\
\hline 2007 & 41,796 \\
\hline 2008 & 41,885 \\
\hline 2009 & 41,601 \\
\hline 2010 & 41,171 \\
\hline 2011 & 40,822 \\
\hline 2012 & 40,492 \\
\hline 2013 & 39,530 \\
\hline
\end{tabular}

Source: Republički zavod za statistiku, 2014.

Most of the number constitutes of old and utilized trees, ready for clearing. These results are indications that Serbia wasn't investing in plum cultivation in past thirty years. During that time cultivation of plums degraded to the level of small farmers, with few manufacturing plants and storage places.

Most famous plum sort of Serbia, Požegača, whit it's characteristic ideal for alteration is almost eradicated from Serbia. Biggest problems of this variety ware fineness of the fruit and intolerance to some fruit diseases. From this variety several hybrids were made, that more or less inherited its characteristic. Most common ones among them in Serbian plum variety are Stanley, Čačanska lepotica $i$ Čačanska rodna. Institutes of Serbia created a number of hybrids, but all of them haven't proved profitable for large scale cultivation. There is also number of native sorts suitable for brandy making, along with some foreign sorts. In the past decade native brandy sorts are slowly being suppressed by earlier mentioned varieties.

Among fruit diseases the most dangerous one for plum in Serbia is virus called Plum pox, 
detected in Serbia first time in 1928 year (Mišić, 2006). Since then it almost destroyed Požegača, till recently most frequent variety of plum in Serbia. During the struggle to overcome the influence of this disease several clones were made, but only some are tolerant to it, with rare clones resistant to disease (Paunović, Ogašanović, 2006). Plum pox virus has big impact on fluctuations of plum yield (Milošević et al., 2010).

Seedling production is one of the most important parts of revitalization of plum cultivation, because most of the plant needs replacement, also breeding of virus-free surface is equally important (Mišić, 2006). Further-more without vegetative surfaces modern style planting isn't possible (Milenković et al., 2006). Dominant substrate for plum in Serbia is native sort called Džanarika, with great type variety, proved unfit for modern cultivation (Nikolić, Rakonjac, 2007). In last decade, changes are made in cultivation techniques, spacing in planting decreases, number of plant in unit area is increasing, free formation of crown is being replaced with spindle formation (Milošević et al., 2008). If agriculture in Serbia want's to turn to intensive cultivation irrigation is the key segment for achieving that goal. From all the fruit corps in Serbia only 11\% is being irrigated, mainly in Vojvodina. State of mechanization in Serbia is devastating, only $10 \%$ of tractors are less than ten years old, and more than $50 \%$ of atomizers are over ten years old (Keserović et al, 2012)

Over ninety percent of plum orchards in Serbia are in private property, and most of the orchards are in rural highland areas (Milošević, Petrović, 2000). Majority of private orchards contains of several smaller parcels, which makes difficult implementation of modern techniques of planting, circumcision, irrigation as well as use of modern mechanization. If there was possibility of usage of modern planting techniques, production of plum can be increased significantly (Glišić et al., 2006).

In comparative look over three main parameters for cultivation of plum in last couple of decades (Tables 6\&7), which are number of bearing trees, annual production and yield per tree, uneven numbers shows lack of organized cultivation, which derives from bad cooperation between state and plum producers.

Table 6. Cultivation of plums in Serbia (1981-2006)

\begin{tabular}{|c|c|c|c|}
\hline Year & number of bearing trees in 000 & annual production (t) & yield per tree (kg) \\
\hline 1981 & 49,839 & 537,490 & 10 \\
\hline 1985 & 48,068 & 327,370 & 6 \\
\hline 1990 & 46,395 & 355,160 & 7 \\
\hline 1995 & 44,652 & 216,250 & 4 \\
\hline 2005 & 42,582 & 304,351 & 7 \\
\hline 2006 & 41,769 & 556,227 & 13 \\
\hline
\end{tabular}

Source: Matković, 2008. 
Ending with year 2006, it can be seen that all three given parameters show grate variations, and number of trees is in constant decline trough entire sown period. Yield per tree shows biggest variation of $31.4 \%$ (Matković, 2008), which states poor state of cultivation level for this period. Numbers began to stabilize at the ending of given period.

Table 7. Cultivation of plums in Serbia (2007-2013)

\begin{tabular}{|c|c|c|c|}
\hline Year & number of bearing trees in 000 & annual production (t) & yield per tree (kg) \\
\hline 2007 & 41,885 & 680,566 & 16 \\
\hline 2008 & 41,885 & 606,767 & 14 \\
\hline 2009 & 41,601 & 662,631 & 16 \\
\hline 2010 & 41,171 & 426,846 & 10 \\
\hline 2011 & 40,822 & 581,874 & 14 \\
\hline 2012 & 40,492 & 391,485 & 10 \\
\hline 2013 & 39,530 & 738,278 & 19 \\
\hline
\end{tabular}

Source: Republički zavod za statistiku, 2014.

In the last decade number of bearing trees continues to decrease, but production shows increase, which is still instable, because yield shows variation similar to the period given in Table 6.

As it can be seen it Tables $6 \& 7$ plum production in Serbia has great variations, which are result of unsupervised cultivation, without the use of modern growing techniques, but it also shows big unused potential, that represents good ground point for future development.

Most of fruit crops in EU are concentrated in southern Europe. Spain and Italy have almost 50\% of all area under fruit, and of all fruit one sixth are apples (Eurostat, 2014).

Big producers of plum in EU are Spain and France with annual total of some $200.000 \mathrm{t}$.

Serbia and Romania are regional leaders in plum production, with similar annual production. If Serbia is to modernize production of plum fast, than it will be possible for Serbia to take the leading role in region, Romania has same production with two times less area under plum crops. Turkey has 20.468 ha of plum crops, and with usage of modern techniques, annual production of 300.000 t represents main rival for Serbia in region for cultivation of plums. Italy, on other hand has modern plum production, and with several times smaller areas under plum has annual average of $170.000 \mathrm{t}$, which stress importance of modern techniques usage in plum cultivation, Greece is another good example of usage of modern techniques with 15,700 t 1.500 ha, but Greece is small producer and doesn't represents threat for Serbian ambitions in plum cultivation. 
Bosnia is another big producer, but with annual total of 111.005 t 79.000 ha, it is clear that Bosnian cultivation faces even bigger problems that Serbian. Bulgaria, Hungary, Macedonia, Austria, Croatia, Slovenia and Montenegro with their numbers in plum production, aren't competitive. Germany isn't big producer, but with annual average of $35.567 \mathrm{t}$, and with only 3.863 ha of plum crops, can be a good example of correct usage of modern techniques in plum cultivation (Table 8).

Table 8. Cultivation of plums in Europe for 2012

\begin{tabular}{|c|c|c|}
\hline Country & area under plum in ha & total production \\
\hline Serbia & 158,000 & 391,485 \\
\hline Bosnia \& Herzegovina & 79,000 & 111,005 \\
\hline Romania & 67,478 & 424,068 \\
\hline Turkey & 20,468 & 297,026 \\
\hline Bulgaria & 17,776 & 22,949 \\
\hline Spain & 16,000 & 205,300 \\
\hline Italy & 11,636 & 172,247 \\
\hline Croatia & 6,700 & 34,580 \\
\hline Macedonia & 6,400 & 71,915 \\
\hline Austria & 5,975 & 43,268 \\
\hline Hungary & 5,700 & 35,567 \\
\hline Germany & 3,863 & 2,190 \\
\hline Slovenia & 3,000 & 8,769 \\
\hline Montenegro & 1,900 & 15,700 \\
\hline Greece & 1,500 & \\
\hline & & \\
\hline
\end{tabular}

Source: fao.org, 2014.

It can be concluded that Serbia is among countries with obsolete techniques in plum cultivation, not only in terms of world plum cultivation, but also in the regional terms. 


\section{Processing of plums}

In ever growing demand for organic food plum is among most wanted, due to her medically proven health benefit (Walkoviak-Tomczak, 2008). Duration of fresh plum season is usually less than 100 days. This states that alteration of plums is potentially very profitable part of plum cultivation.

There are three types of plum alteration:

- Warm processing, which is divided in:

- production of dried plums

- production of jams and marmalade

- production of juices

- production of concentrates

- Cold processing, which contains of:

- freezing of whole fruit

- freezing of hand-cut fruit

- freezing of machine cut fruit

- Brandy production.

Most of the annual production of plum in Serbia is being processed. More than $80 \%$ of processed plum is used to make brandy, rest is being processed in several products. Germany, with annual production similar to Serbian, and Great Britain, which imports plum, make over 100 hundred plum products, while Serbia makes less than five. Advancement of processing of fruit enables more favorable production and economic results, compared with results in fresh fruit production (Lukač, Bulatović et al., 2012).

There are several reasons for this state: obsolete processed techniques, shortage of processing capacities, low demand of food industry for plum...

Dried plum is a rich source of numeral bioactive compounds, such as phenolic and flavonoids, providing numerous health benefits (Mehta et al., 2014). Dried plum processing has long history in Serbian production. Advantage of this type of alteration is that in can be used as final product, but also as semi-product for later procession. Požegača was mainly used for drying, because of her caracteristic. Drying was made in traditional hand-made dryers, whit usage of wood smoke. Today this technique is obsolete. In Serbia today thare are 340 industrialised dryers, around 350 mini dryers and some 5000 oldfashoned dryers. Main weaknesses are obsolete of tehnology and process of preparing plum for drying. Modern process of drying is achevable with better sortimentation of fruit sutable for drying, plantation suitable for mechanized picking, building modern dryers, and standadization of drying process acording with modern standards (Marković, 2000). Also, implementation of eco-fiendly ttechnologies is necessary for acheiving modern level of plum drying (Zlatanović, 2012). Variety of plum such as Stenley, Požegača, Čačanska rodna are most suitable for drying in Serbian sortiment of today, from which Čačanska rodna proved most profitable (Mitrović et al., 2000). 
Annual production of dryed plum for past century in Serbia was around $20.000 \mathrm{t}$, while today doesn't go over couple of ton, from which of industrial production goes less than $5 \%$. In annual processing of plum in Serbia dryed plum participate with less than $6 \%$.

Other branches of warm processing like jam production are sporadical and minore in terms of profitability in current state of plum cultivation in Serbia. For most of warm processing products Serbia doesn't have suitablle tehnology.

Cold procession of plums developed in Serbia in last couple of decades. Serbian capacities today amounts 100 refrigerators of $3000 \mathrm{t}$, and 150 refrigerators of $1000 \mathrm{t}$ (Keserović et al, 2012), most of which are thnologicaly obsolete (Janković, Mašović, 2000). But even this capacities aren't fully used, which leads to conclusion that Serbia has unused potential in this branch of processing. Also tehnology used for cold procession is obsolete, and without the usage of modern tehnologyes like MAP, which is packing tehnology that prevents contact with chemicals in process of conservation, export won't be possible (Janković, Stevanović, 2006).

Brandy production, of plum brandy caled Šljivovica, makes over $80 \%$ of pulm procession in Serbia. And from this number most comes from private manufacturers, that makes brandy for private consumption.

Annual production of brandy amounts 40.400 millions of litres for past several decades, less of $5 \%$ is high quality brandy. Here lies waste unused potential of Serbian plum production. More than $50 \%$ of all production come from varietys suitable for brandy making. There is a number of native variety used for brandy production, some of which proved suitable for high quality brandies, like variety called Crvena ranka (NenadovićMratinić et al., 2006). Požegača whit its caracteristic was most suitable for making brandy, but it is reduced on variety of local significanse today.

High class plum brandy, with established trademarks and protected origine, are rare amongst plum brandy in Serbia, some of them are:

- Žuta osa, maker „Flores“, most famous Serbian plum brandy

- Manastirka, maker „Prokupac“

- Baljevka, maker „Srbijanka““

- Stara sokolova, maker „Bogdanović“

- Povlenka, maker „Povlen“

- Suboborska šljiva, maker „Jutra“, made exclusive from variety Požegača

There is also a number of private manufacturers, that whit the proper branding can be competitive, both on domestic and export market.

Serbian plum brandy is most famous for its characteristic aroma and harmonical taste, but to make it competitive to leading world brands, much need's to be done. In bottleing process which takes three and a half years, changes are needed in picking varieties, planting, ways of harvest, fruit preparation, distilling techniques, techniques of brady ageing, standardization in botteling, brand making, to mention some of them (web.stat. 
gov.rs/WebSite/Public/PageView.aspx?).

Another big problem is competitive ability of serbian food companies, that with unproductivness, inefficency, low level of technology and inadequate knowhow, can't match level of standardization needed for modern food production (Bešić et al., 2014). On the other hand, prepared fruit is among products that can increase Serbian chances of export possibilities (Ignjatijević et al., 2014).

Main problems of plum processing in Serbia are obsolete tehnology, lack of production capacities, poor segmentation in warm procession, which contains of only a couple of products, great participation of brandy making in total of processing, most of wich is for private consumption, and low number of final products.

\section{Export}

In modern state of Serbia, export of plum was always considered profitable. In fact, it was the first Serbian product to go on international market in year of 1867, 4.200 ton of dried plum.

Export of plum and products of plum stabilized in years after II world war, when Serbia had export on both East and West Europe market. After thitenig of regulation for export on West Europe market, and folowing end of Soviet union, Serbia lost boat of the markets, and revived its export in the mid-ninetes.

In renewed Serbian export, fruit participate with $17 \%$, plum participate with $10 \%$ in fresh fruit export, and less than $1 \%$ in agricutural export in total. Serbia has determined cost for fresh and dried plum, boat uncompetitive. In last fifteen years world average for one ton of fresh plum were $650 \$$, while Serbian was $188 \$$ per ton, and for dried plum Serbian price was $1062 \$$ per ton, and world average was $1798 \$$.

Even so the export was revived, it never acheved former figures. Fresh plum export has follen from annual of $10.000 \mathrm{t}$ to 650 , dried plum from $30.000 \mathrm{t}$ to 817 , export of frozen plum fell from former $6.000 \mathrm{t}$ to 3.500 , but never the less is most profitable plum export product.

In years between 1996 and 2006, export of plum began to revitalize slowly, but it is still far from being profitable part of Serbian export (Table 9).

Table 9. Serbian export of plum and plum products (1996-2006.)

\begin{tabular}{|c|c|c|}
\hline Year & quantity in t & value in 000 \$ \\
\hline 1996 & 5,980 & 2,772 \\
\hline 1997 & 5,780 & 3,536 \\
\hline 1998 & 7,143 & 3,462 \\
\hline 1999 & 11,376 & 4,066 \\
\hline
\end{tabular}




\begin{tabular}{|c|c|c|}
\hline Year & quantity in t & value in $\mathbf{0 0 0} \mathbf{\$}$ \\
\hline 2000 & 11,785 & 4,529 \\
\hline 2001 & 16,507 & 5,550 \\
\hline 2002 & 9,225 & 3,948 \\
\hline 2003 & 25,380 & 8,500 \\
\hline 2004 & 19,039 & 9,393 \\
\hline 2005 & 12,891 & 7,970 \\
\hline Year & quantity in t & value in $\mathbf{0 0 0} \mathbf{\$}$ \\
\hline 2006 & 26,838 & 15,383 \\
\hline
\end{tabular}

Source: Matković, 2008.

It took almost fiften years for Serbian plum export in total, to obtaine export level of just one plum export product from pre-ninety's period. In last decade Serbian export continued to slowly revitalize, but annual totals are stil in rank of Srerbian export of dried plums in time of SFRJ (Table 10). Numbers stres absence of strategy in plum export.

Table 10. Serbian export of plum and plum products (2007-2010)

\begin{tabular}{|c|c|}
\hline Year & quantity in t \\
\hline 2007 & 30,552 \\
\hline 2008 & 22,690 \\
\hline 2009 & 27,841 \\
\hline 2010 & 22,248 \\
\hline
\end{tabular}

Source: fao.org, 2014.

Dried plum export was, for a long time, one of the strongolds of Serbian export. During the past century, ending with 1990., export never fell under 10.000 ton per year, today particitates in plum export with less than $10 \%$.

Frozen plum export is most profitable part of Serbian plum export in last twenty years, with participation of over $50 \%$, and it is the product that keeps Serbian plum on the international market.

Export of fresh plum had significant results in the past, but it had never achieved stable figures, in order to bring steady income.

Plum brandy export had steady figures in seventies and eighties of past century, with annual export of over $1.000 \mathrm{t}$, but during the revival of export in mid-nineties wasn't renewed. 
Serbian plum export is poorly segmentated, whith couple of product participating, with uncompetitive price and without cleat strategy for breaktrough on world market.

In the world market of plums, of top five exporters, Spain and Italy comes from Europe, Spain in in second place in the world in export of plum, and represents major competitor for Serbia in Europe, with average annual export of 74.000 t, Serbia holds sevnth place, infront of France, but after Netherlands, wich has symbolical area under plum and mainly trades whith it, Germany, Belgium, and Poland are also among major exporters, but with annual variations, and from region, besides Hungary, whose export shows grate variations, Turkey has stable exports, but whith under 5.000 t per year (Table 11).

Table 11. World exporters of plum (2007-2010), shown in tons

\begin{tabular}{|c|c|c|c|c|c|}
\hline Country & $\mathbf{2 0 0 7}$ & $\mathbf{2 0 0 8}$ & $\mathbf{2 0 0 9}$ & $\mathbf{2 0 1 0}$ & $\mathbf{2 0 0 7 - 2 0 1 0}$ \\
\hline Chile & 105,055 & 85,853 & 95,057 & 74,533 & 360,498 \\
\hline Spain & 82,221 & 89,263 & 88,537 & 88,892 & 348,913 \\
\hline USA & 48,368 & 62,361 & 44,591 & 56,969 & 212,016 \\
\hline South Africa & 43,742 & 49,283 & 56,883 & 46,409 & 196,317 \\
\hline Italy & 38,712 & 41,218 & 40,360 & 56,569 & 176,859 \\
\hline Netherlands & 34,567 & 33,474 & 36,131 & 26,218 & 130,390 \\
\hline Serbia & 30,552 & 22,690 & 27,841 & 22,248 & 103,331 \\
\hline France & 24,026 & 13,372 & 19,855 & 19,082 & 76,335 \\
\hline Poland & 9,688 & 22,704 & 19,949 & 7,222 & 59,563 \\
\hline Hungary & 7,945 & 17,011 & 17,011 & 17,572 & 59,539 \\
\hline Argentina & 18,621 & 15,528 & 11,906 & 8,474 & 54,529 \\
\hline China & 7,513 & 9,759 & 15,856 & 11,385 & 44,531 \\
\hline Germany & 7,538 & 5,164 & 5,728 & 4,881 & 23,311 \\
\hline Turkey & 3,498 & 3,170 & 6,137 & 7,678 & 20,483 \\
\hline Belgium & 5,426 & 3,777 & 4,418 & 2,552 & 16,173 \\
\hline
\end{tabular}

Source: fao.org, 2014.

Among top ten importers of fresh plum in the world for past five years are Germany, Russian Federation, China, France, United Kingdom, Canada, Netherlands, Italy, Belgium and United States, with two-thirds of total value of imported plum, for period from 2009. to 2013. Two major importers of plum are Germany and Russian Federation, boat increasin import of plums in last five years (trademap.org). From all of the major, sevan are from Europe, from teh markets were Serbia sold plum and plum products in the past. Today, Serbia has stable export in Russian Federation, but with much smaller volume. Nearness of major plum import markets must be used for improvement of Serbian export results. Many reasons exist for current state of Serbian production of plum, main of which are lack of financial support, low level of production techniques and technology, unsatisfactory control of brandy making process, as well as brandy selling, low purchase price and weak export possibilities (Ševarlić, 2000). 


\section{Conclusion}

In order to revitalize Serbian plum production several steps shuld be made:

- Enactment of state strategy for revitalization of plum production, that will take into consideration state of plum cultivation in Serbia, world results in plum cultivation, compared state of Serbian and regional plum production, possibility of plum cultivation developmnet and achievable plase on international market for Serbian plum

- Adoption of agricultural laws that will stimulate cultivation of plum, among other Low on integral production, Low on seedlings production, makeing of Official fruit and winegrowing regionalization, Regulation for agricultural cooperation...

- Foundation of fonds for support of entrepreneurs, considering the fact that over $95 \%$ of plum corps are of private ownership and the capitlaist orientation of Serbian economy

- Introduction of new, better organized services for technical assistance, most of the owners of agricultural farms are aged and uneducated, futhermore, agricultural experts have little of practical knowlege

- Introduction of modern standards of cultivation and processon of plums, that will inprove state in cutltivation, wich will lead to several times bigger ressults in production, as well as further diversification in alteration of plums, enabling Serbia greather shance for export, and making her not only an exporter of fresh and semi-final products, but also of final produsts exporter

- Making marketing strategy for plum export, that will accurately estimate Serbian plum export chances, giving guidelines for chooseing profitable products, finding suitable markets, branding of star products, as well as making the price of Serbian plum products competitive in world scale.

Without inplemnetation of these steps it will be difficult, if not impossible, to obtain level of production needed for profitable cultivation of plum in Serbia.

\section{Literature}

1. Bešić C., Ćoćokalo, D., Đorđević, D., Bogetić, S. (2014): The analysis of aspects of food industry competitiveness in Serbia, Ecomonics of Agricultire, Institut za ekonomiku poljoprivrede, Beograd, Srbija, Vol. 2014, No. 3, pp. 647-659

2. Biljna proizvodnja, šljiva, avalilable at: web.stat.gov.rs/WebSite/Public/PageView.aspx?)

3. Čobrda, A. (2005): Proizvodnja i promet šljive u Republici Srbiji, magistarska teza, Poljoprivredni fakultet, Univerziteta u Novom Sadu, Novi Sad, Srbija

4. Eurostat regional yearbook, available at: ec.europa.eu/eurostat/web/productsstatistical-books/-/KH-HA-14-001

5. Glišić, I., Milošević, T., Glišić, I. (2006): Utrošak vremena za formiranje uzgojnog oblika kod nekih sorti šljive gajenih u gustoj sadnji, 1 simpozijum o šljivi Srbije, Čačak, Srbija

6. Ignjatijević, S., Čavlin, M., Đorđević, D., (2014): Measurament of comparative advantages of processed food sector of Serbia in the increasing the export, 
Ecomonics of Agricultire, Institut za ekonomiku poljoprivrede, Beograd, Srbija, Vol. 2014, No. 3, pp. 677-693

7. Janković, M, Mašović, C. (2000): Tehnologija hlađenja i smrzavanja šljive, Savetovanje, Dani šljive, Koštunići, Srbija

8. Janković, M., Stevanović, C. (2006): Pakovanje šljiva u modifikovanoj atmosferiMAP, 1 simopozijum o šljivi srbije, Čačak, Srbija

9. Keserović, Z., Magazin, N., Kurjakov, A., Dorić, M., Tošić, J. (2012): Voćarstvo, Popis poljoprivrede 2012, Poljoprivreda u Republici Srbiji, Republički zavod za statistiku, Beograd, Srbija (avaliable at pod2.stat.gov.rs/ObjavljenePublikacije/Popis2012)

10. List of importers of stone fruit, available at: www.fao.org./food export

11. Lukač Bulatović, M., Rajić, Z., Ljubanović Ralević, I. (2012): Economic features of processed fruit production in Serbia, Ecomonics of Agriculture, Vol. 59, No. 4, pp. 715-725,

12. Marković, V. (2000): Istorija sušenja šljive u našoj zemlji, Savetovanje, Dani šljive, Koštunići, Srbija

13. Matković, M. (2008): Razvojne mogućnosti proizvodnje i prerade šljive u Srbiji, magistarska teza, Poljoprivredni fakultet, Univerziteta u Novom Sadu, Novi Sad, Srbija

14. Mehta, S., Soni, N., Satpathy, G., Gupta, R. (2014): Evaluation of nutritional, phytochemical, antioxidant and antibacterial activity of dried plum (Prunus domestica), Journal of Pharmacognosy and Phytochemistry, New Delhi, India, Vol. 3, No. 2, pp. 166-171

15. Milenković, S., Cerović, R., Ogašanović, D., Janković, M. (2006): Sadašnje stanje i perspektive šljivarstva Srbije, 1 simpozijum o šljivi Srbije, Čačak, Srbija

16. Milošević, T.M., Glišić, I.P., Milošević, N.T., Glišić, I.S. (2010): Plum pox virus as a stress factor in the vegetative growth, fruit growth and yield of plum (Prunus domestica L.) cv. 'Cacanska Rodna', European Journal of Plant Pathology, Wageningen, Nethetlands, Vol. 126, No. 1, pp. 73-79

17. Milošević, T., Petrović, S. (2000): Stanje, problemi i perspektiva proizvodnje šljive u brdsko-planinskom području centralne Srbije, Savetovanje, Dani šljive, Koštunići, Srbija

18. Milošević, T., Zornić, B., Glišić, I. (2008): A comparison of low-density plum plantings for differences in establishment and management costs, and in returns over the first three growing seasons - a mini-review, Journal of Horticultural Science and Biotechnology, The James Hutton Institute Invergrowrie, Dundee, UK, Vol. 83, No. 5, pp. 539-542

19. Mitrović, O. Mitrović, M., Gavrilović-Damjanović, J., Popović, J., Kandić, M. (2000): Problematika sušenja šljive, Savetovanje, Dani šljive, Koštunići, Srbija

20. Mišić, P. (2006): Šljiva, Partenon, Beograd, Srbija, ISSN: 86-7157-291-9.

21. Nenadović-Mratinić, E., Milatović, D., Đurović, D., Nikčević, N. (2006): Pogodnost autohtonih sorti šljive za proizvodnju rakije, 1 simpozijum o šljivi Srbije, Čačak, Srbija

22. Nikolić, D., Rakonjac, V. (2007): Divergence of myrobalan (Prunus cerasifera 
Ehrh.) types on the territory of Serbia, Genetika, Društvo genetičara Srbije, Zemun, Srbija, Vol. 39, No. 3, pp. 333-342

23. Paunović, G., Ogašanović, D. (2006): Dosadašnji rezultati Centra za voćarstvo i vinogradarstvo na proučavanju i rešavanju problema šarke, 1 simpozijum o šljivi Srbije, Čačak, Srbija

24. Plum exporters, available at: www.fao.org/plum export

25. Plum and sloes, area harvest, production quantity and yield, available at: www.fao.org/plum

26. Ševarlić, M. (2000): Proizvodnja, prerada i plasman šljive i proizvoda od šljive u svetu i Sr Jugoslaviji, Savetovanje, Dani šljive, Koštunići, Srbija

27. Walkowiak-Tomczak, D. (2008): Characteristics of plums as a raw material with valuable nutritive and dietary properties - a review, Polich journal of food and nutrition sciences, Institute of Animal and Food Research of Polish Academy of Sciences, Olsztyn, Poland, Vol. 58, No. 4, pp. 401-405

28. Zlatanović, I. (2012): Primena savremenih tehnologija sušenja, Poljoprivredna Tehnika, Poljoprivredni fakultet, Univerzitet u Beogradu, Zemun, Srbija, Vol. 37 , No. 4, pp. 23-30.

\section{MOGUĆNOSTI PROIZVODNJE ŠLJIVE U REPUBLICI SRBIJI}

\section{Milutin Matković ${ }^{2}$}

\section{Apstrakt}

Proizvodnja šljive uvek je bila jedna od najvažnijih grana poljoprivrede u Srbiji. U modernoj istoriji Srbije proizvodnja šljiva bila je jedan od važnih delova srpske ekonomije, narčito ako se ima u vidu da predstavlja jedan od prvih srbijanskih izvoznih proizvoda.

Poljoprivreda je označena kao jedan od motora revitalizacije Srbijanske privrede. Šljiva je najrasprostranjenija voćna vrsta u Srbiji. Srbija se nalazi među pet vodećih zemalja po površinama pod šljivom. Zapadna Evropa ima najveće tržište šljive $i$ proizvoda od šljive na svetu. Izvoz šljive iz Srbije je zanemarljiv. Srbija ima potencijal da postane regionalni lider u izvozu šljive. Variranja u rezultatima proizvodnje šljiva pokazuju da je neophodna modernizacija u svim aspektima, kako bi se dostigao savremeni nivo u proizvodnji šljive.

Kako bi se oživela proizvodnja šljive i učinila profitabilnom za izvoz, zajednička akcija svih relevantnih faktora je neophodna. Ovaj članak će pokušati da da uvid u stanje proizvodnje šljive, kao i da predloži moguće smernice za njenu revitalizaciju.

Ključne reči: uzgoj, šlive, razvoj, izvoz, revitalizacija

2 Mr Milutin Matković, student doktorskih studija, Krusevačka ulica br. 21, 11000 Beograd, Republika Srbija, Telefon: +381 642787 238, E-mail: milutin.matkovic@gmail.com 